\title{
Cyclooxygenase-2 inhibitor and interferon- $\beta$ synergistically induce apoptosis in human hepatoma cells in vitro and in vivo
}

\author{
NOBUHIRO NAKAMOTO ${ }^{1}$, HAJIME HIGUCHI ${ }^{1}$, HIDEAKI KANAMORI ${ }^{1}$, SATOSHI KURITA ${ }^{1}$, \\ SHINICHIRO TADA ${ }^{1}$, HIROMASA TAKAISHI $^{1}$, KYOKO TODA $^{2}$, TAKAYA YAMADA ${ }^{2}$, \\ NAOKI KUMAGAI ${ }^{3}$, HIDETSUGU SAITO ${ }^{1}$ and TOSHIFUMI HIBI ${ }^{1}$ \\ ${ }^{1}$ Department of Internal Medicine, School of Medicine, Keio University, Tokyo; Departments of \\ ${ }^{2}$ Biomedical Laboratory and ${ }^{3}$ Research Center for Liver, Kitasato Institute Hospital, Japan
}

Received February 8, 2006; Accepted April 11, 2006

\begin{abstract}
Recent clinical trials have shown that interferon (IFN) is effective for chemoprevention against hepatocellular carcinoma (HCC). However, it remains controversial as to whether IFN exerts direct cytotoxicity against HCC. Cyclooxygenase (COX)-2 also plays a role in hepatocarcinogenesis and may mediate resistance to apoptosis in HCC. Therefore, we aimed to elucidate the combined effect of COX-2 inhibitor, NS-398, and IFN on in vitro growth suppression of HCC using 3 hepatoma cell lines (HepG2, PLC/PRF/5, and Huh7) and in vivo nude mouse xenotransplantation model using Huh7 cells. Only minimal growth inhibition was observed after treatment with IFN- $\beta$ alone in the 3 hepatoma cell lines. In contrast, treatment with NS-398 and IFN-ß synergistically inhibited cell proliferation in dose- and time-dependent manner. Apoptosis was identified by 4',6-diamidino-2phenylindole dihydrochloride and fluorescent staining. IFN-B up-regulated the expression of TRAIL, while NS-398 increased the expression of TRAIL receptors (especially of death receptor 5). Subsequently, activation of caspase- 8 and caspase-3 was observed following the treatment with NS-398 and IFN-B. Blockade of TRAIL with a specific antibody attenuated this apoptosis. Furthermore, we found that IFN- $\beta$ up-regulated COX-2 expression in Huh7 cells, and NS-398 might suppress the up-regulated COX-2 activity downstream of IFN signaling. In vivo experiment showed the combined regimen with NS-398 and IFN- $\beta$ reduced the growth of xenotransplated HCCs in nude mice. In conclusion, NS-398 is sufficient to overcome IFN resistance in hepatoma cells through the TRAIL/TRAIL receptor pathway, therefore, the
\end{abstract}

Correspondence to: Dr Hidetsugu Saito, Department of Internal Medicine, School of Medicine, Keio University, 35 Shinanomachi, Shinjuku-ku, Tokyo 160-8582, Japan

E-mail: hsaito@sc.itc.keio.ac.jp

Key words: TRAIL, death receptor, Prostaglandin E2, nude mice, Huh7 combination would appear to be a new therapeutic regimen for HCC.

\section{Introduction}

Interferon (IFN) plays an essential role in both antiviral and antitumor host defenses. Recent clinical trials have shown that IFN is effective in preventing the development of hepatocellular carcinoma (HCC) $(1,2)$, but its precise mechanism has not yet been clarified. Recently it was found that IFN induces apoptosis by up-regulating tumor necrosis factor (TNF)-related apoptosis-inducing ligand (TRAIL) in immune cells (3), melanoma cells (4), and even in solid tumor cells $(5,6)$. These results suggest that autocrine TRAIL production is involved in the induction of apoptosis. TRAIL binds to two apoptosis-inducing receptors, TRAIL R1 (DR4) and TRAIL R2 (DR5); and two additional cell-bound receptors incapable of transmitting an apoptotic signal, TRAIL R3 (DcR1) and TRAIL R4 (DcR2). Both DR4 and DR5 have an intracellular death domain to transmit the apoptotic signal. Stimulation of DR4 and DR5 results in recruitment and activation of caspase- 8 via Fas-associated death domain (FADD) (7). Activated caspase- 8 then directly activates caspase-3, -6, and -7 (8) or activates the intrinsic mitochondria-mediated pathway through Bid cleavage (9). In $\mathrm{HCC}$, it is unclear as to whether IFN is directly cytotoxic, and indeed, most hepatoma cell lines are resistant to IFNmediated apoptosis in vitro (10). Consequently, combination agents are necessary to overcome IFN resistance.

Non-steroidal anti-inflammatory drugs (NSAIDs) inhibit cell proliferation and induce apoptosis in a variety of cancer cell types (11-13) by inhibiting cyclooxygenase (COX). Two isoforms of COX, COX-1 and -2 , have been identified. COX-1 is constitutively expressed in most tissues and is associated with PG production required for normal physiological function. In contrast, $\mathrm{COX}-2$ is induced at the site of inflammation by mitogens, cytokines, and other factors. Overexpression of COX-2 has been reported in many human cancers (14-16), and a role in an early stage of hepatocarcinogenesis has also been described $(17,18)$. Recent studies demonstrated that a selective COX-2 inhibitor reduced the growth of a variety of cancers, including HCC, in vivo $(19,20)$ 
A
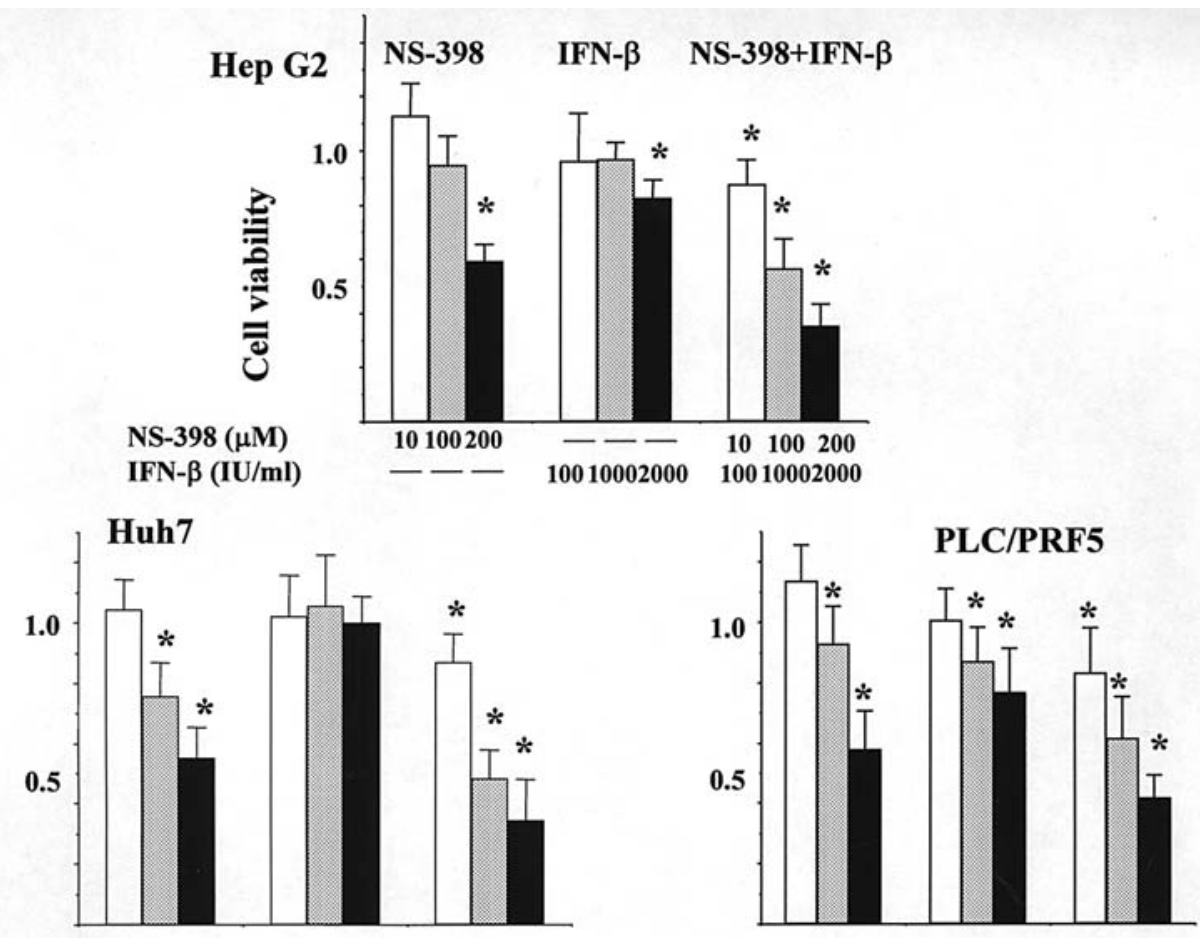

B

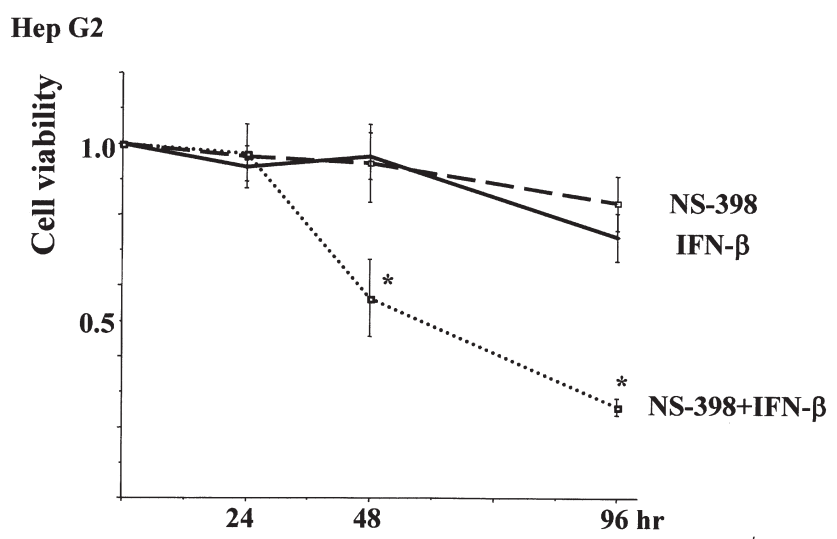

and in vitro (21). The mechanism accounting for its antiproliferative effect in cancer cells includes: inhibition of COX-2 and subsequent PGE2 activity (a COX-2-dependent pathway) (22), inactivation of the protein kinase, AKT (11), inhibition of $\mathrm{Ca}^{2+}$ influx into the endoplasmic reticulum (23), down-regulation of Bcl-2 (24), and induction of cell cycle arrest (25). Recently Liu et al (26) reported that celecoxib, a selective COX-2 inhibitor, induced DR5 up-regulation and subsequent apoptosis in human non-small lung cell carcinoma.

C
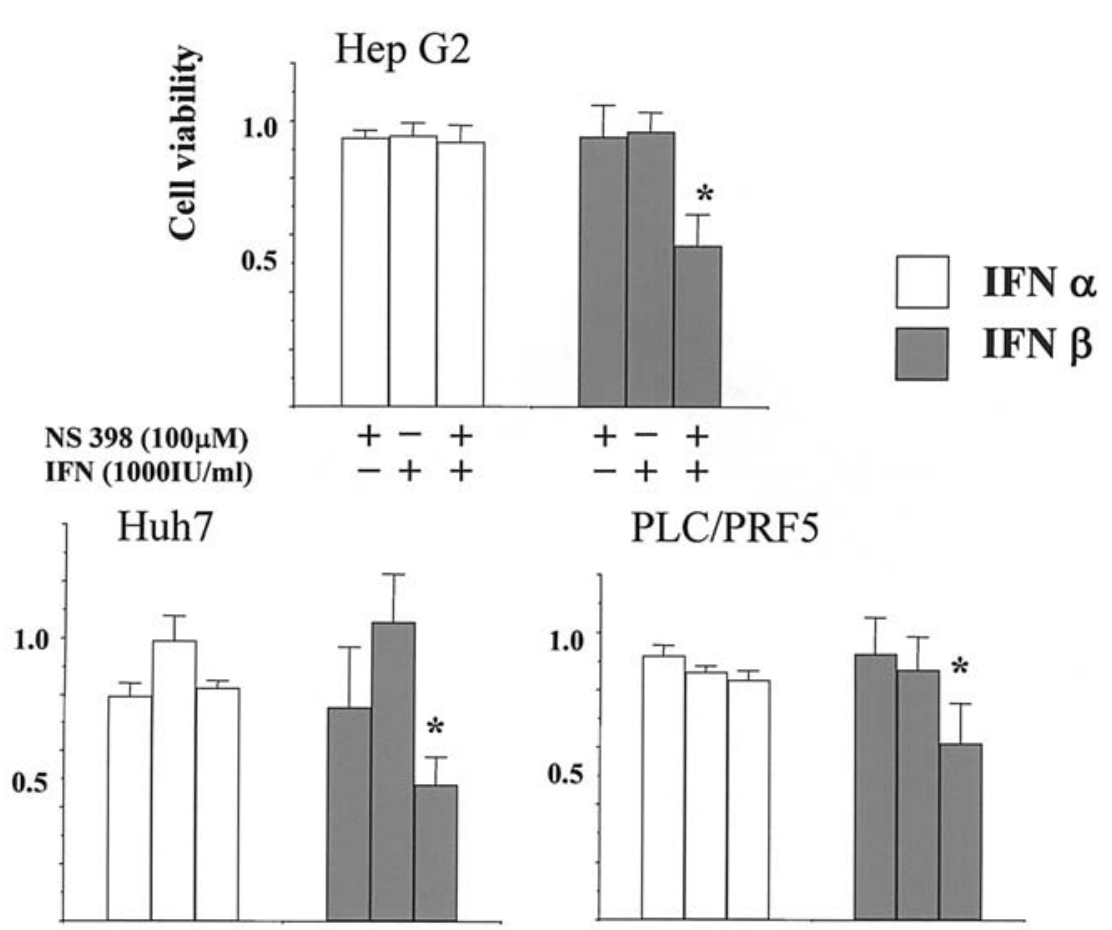

PLC/PRF5

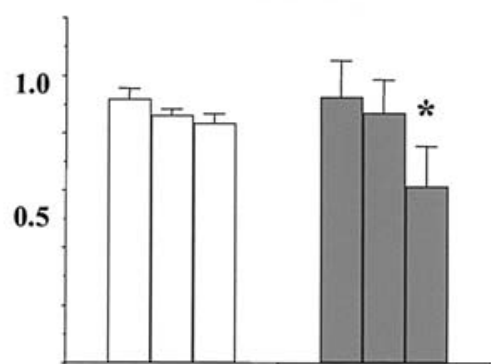


D
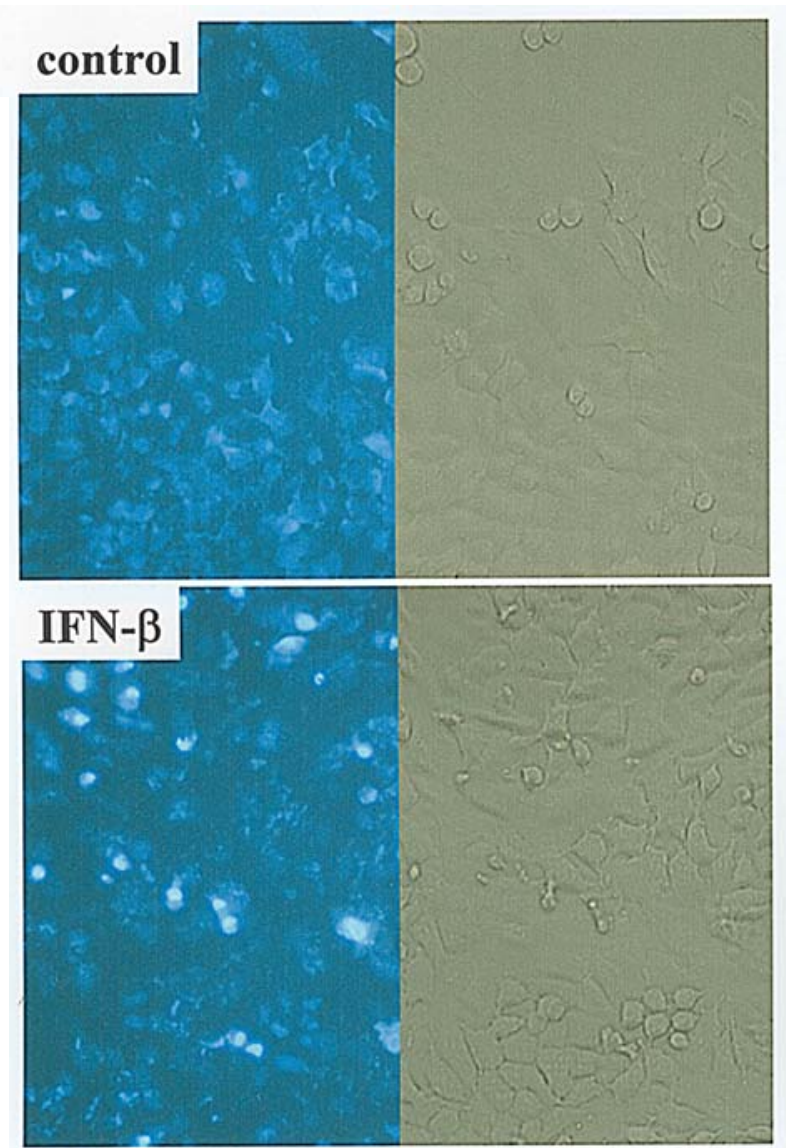
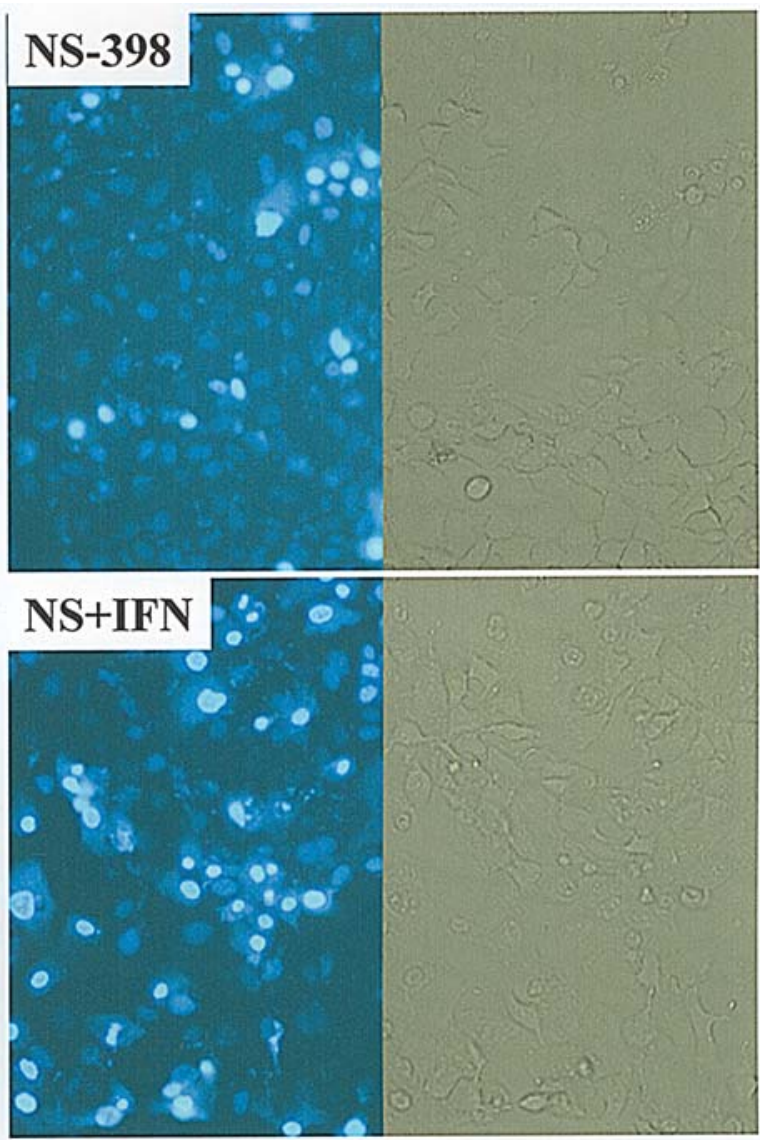

Figure 1. Effect of IFNs and NS-398 on cell growth and apoptosis in hepatoma cell lines. A, HepG2, Huh7, and PLC/PRF cells were treated with IFN-3 (100, $1000,2000 \mathrm{IU} / \mathrm{ml})$ and/or NS-398 $(10,100,200 \mu \mathrm{M})$ for $48 \mathrm{~h}$. Cell viability was determined by MTS assay. Data represent mean \pm SD of 12 samples. ${ }^{*} \mathrm{p}<0.05$ compared with control cells in each cell line. B, HepG2 cells were treated with IFN-B (1000 IU/ml) and/or NS-398 (100 $\mu \mathrm{M})$. Cell viability at 24,48 , and $96 \mathrm{~h}$ following the administration was determined by MTS assay to assess time-dependence. Data represent mean \pm SD of 6 samples. ${ }^{*}$ p $<0.001$ compared with cells treated with NS-398 or IFN- $\beta$ alone at the indicated time-points. C, The growth-inhibitory effect of IFN- $\alpha$ (1000 IU/ml) in combination with NS-398 (100 $\mu$ M) at $48 \mathrm{~h}$ post-treatment was compared with that of IFN-B $(1000 \mathrm{IU} / \mathrm{ml})$ in the 3 hepatoma cell lines. Data represent mean \pm SD of 6 samples. ${ }^{*}$ p $<0.01$ compared with cells treated with NS-398 or IFN-B alone in each cell line. D, DAPI staining was performed to detect apoptosis in PLC/PRF/5 cells $48 \mathrm{~h}$ following each treatment. The result shown is one representative example from three experiments. A similar effect was observed in Huh7 and HepG2 cells.

These observations suggest that the combination of IFN with COX-2 inhibitors might amplify apoptosis of cancer cells by up-regulating the expression of both TRAIL and DR5. To test this hypothesis, we examined the apoptosisinducing effect of combination treatment with IFN and a selective COX-2 inhibitor, NS-398, on human HCC cell lines both in vitro and in vivo.

\section{Materials and methods}

Reagents. NS-398 was purchased from Cayman Chemical (Ann Arbor, MI, USA). NS-398 was dissolved in dimethyl sulfoxide (DMSO) and stored at $-80^{\circ} \mathrm{C}$. Human recombinant IFN- $\alpha$ was purchased from Shering-Plough K.K. (Osaka, Japan) and IFN- $\beta$ was purchased from Mochida Pharmaceutical Co. (Tokyo, Japan). Human recombinant TRAIL and neutralizing monoclonal anti-TRAIL was purchased from Alexis Biochemicals (San Diego, CA, USA), and PGE2 was purchased from Cayman Chemical.

Cell lines and cell culture. Human hepatoma cell lines, HepG2, Huh7, and PLC/PRF/5 cells, were obtained from the Human Science Research Resources Bank (Osaka, Japan).
The 3 cell lines were cultured in DMEM with $1 \%$ penicillin/ streptomycin and $10 \%$ heat-inactivated FBS at $37^{\circ} \mathrm{C}$.

Cell growth assays. Cells $\left(3 \times 10^{3}\right.$ per well) were seeded in triplicate in 96-well microplates and allowed to attach. Twentyfour hours later, the medium was discarded and replaced with fresh medium containing various concentrations of NS-398 and/or IFN. The medium was changed every $48 \mathrm{~h}$, and the number of viable cells at each time point was determined by MTS assay (Promega, Madison, WI, USA) according to the manufacturer's instruction. The effect of soluble TRAIL, TRAIL neutralizing antibody, and PGE2 on cell growth was also evaluated.

Western blot analysis. Cells were washed twice with ice-cold PBS and lysed for $30 \mathrm{~min}$ on ice with lysis-buffer $(30 \mathrm{mmol} / \mathrm{l}$ Tris $\mathrm{pH} 7.5,150 \mathrm{mmol} / \mathrm{l} \mathrm{NaCl}, 10 \%$ glycerol, $1 \mathrm{mmol} / \mathrm{l} \mathrm{PMSF}$, $1.5 \%$ Triton-X 100, and protease inhibitors). Samples containing $50 \mu \mathrm{g}$ protein were separated by SDS-PAGE and electrophoretically transferred to Hybond-P nitrocellulose membranes (Amersham-Pharmacia Biotech Inc., Piscataway, NJ, USA). After blocking for $60 \mathrm{~min}$ at room temperature (RT) with 5\% non-fat milk in Tween-TBS, membranes were 
A
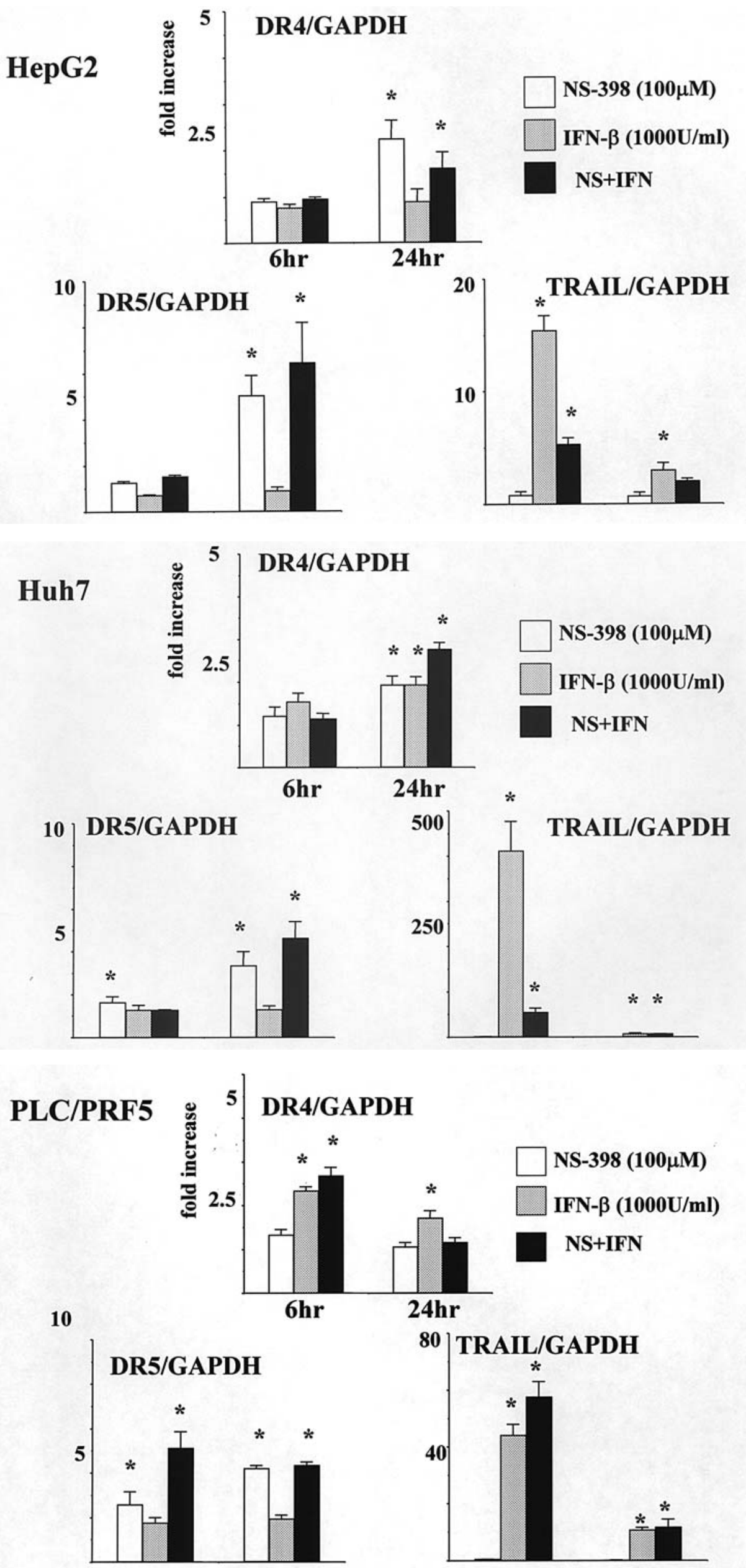


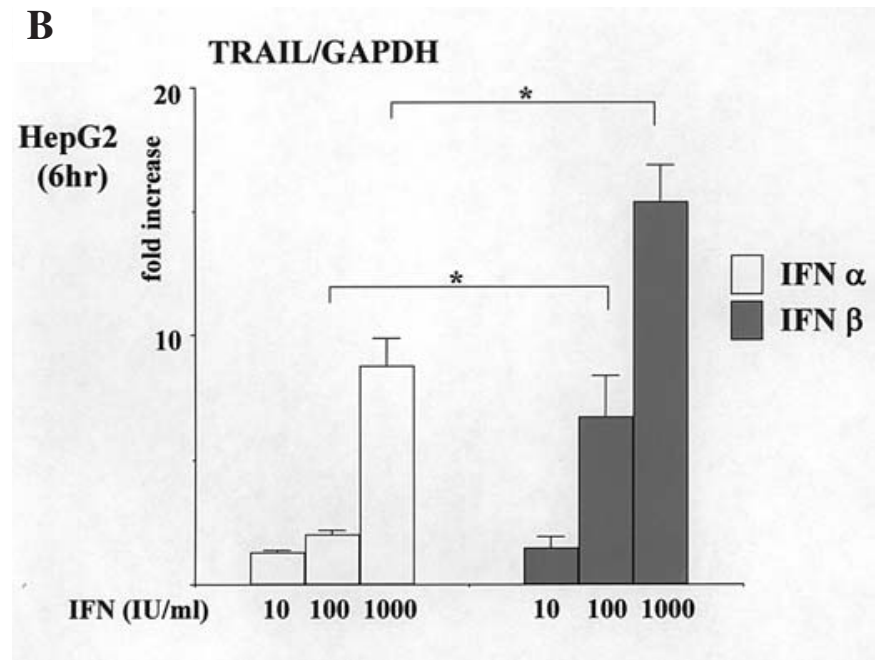

Figure 2. Transcription and expression of DR4, DR5, and TRAIL detected by real-time RT-PCR and Western blotting in hepatoma cell lines. A, Cells were treated with IFN-B $(1000 \mathrm{IU} / \mathrm{ml})$ and/or NS-398 $(100 \mu \mathrm{M})$ for 6 or $24 \mathrm{~h}$. Expression levels of DR4, DR5, and TRAIL mRNA were determined by real-time RT-PCR as described in Materials and methods. The expression of each mRNA was normalized according to the expression levels of housekeeping GAPDH, and the increase of expression in comparison to that of control cells was calculated. Data represent mean \pm SD of 4 samples. ${ }^{*} \mathrm{p}<0.05$ compared with control cells in each cell line. B, The difference in the effects of IFN- $\alpha(0-1000 \mathrm{IU} / \mathrm{ml})$ and IFN- $\beta(0-1000 \mathrm{IU} / \mathrm{ml})$ on induction of TRAIL mRNA were evaluated. HepG2 cells were treated with IFN- $\alpha$ $(0-1000 \mathrm{IU} / \mathrm{ml})$ or IFN- $3(0-1000 \mathrm{IU} / \mathrm{ml})$ for $6 \mathrm{~h}$. Data are represent mean $\pm \mathrm{SD}$ of 4 samples. ${ }^{*} \mathrm{p}<0.01$ compared with the increase in IFN- $\alpha$ treated cells at the indicated concentrations. $\mathrm{C}, \mathrm{HepG} 2$ and Huh7 cells were treated with IFN-B $(1000 \mathrm{IU} / \mathrm{ml})$ and/or NS-398 $(100 \mu \mathrm{M})$ for $24 \mathrm{~h}$, and the expression of each protein was analyzed by Western blotting. The result shown is a representative example from 3 experiments.

C

Hep G2

Huh7

TRAIL
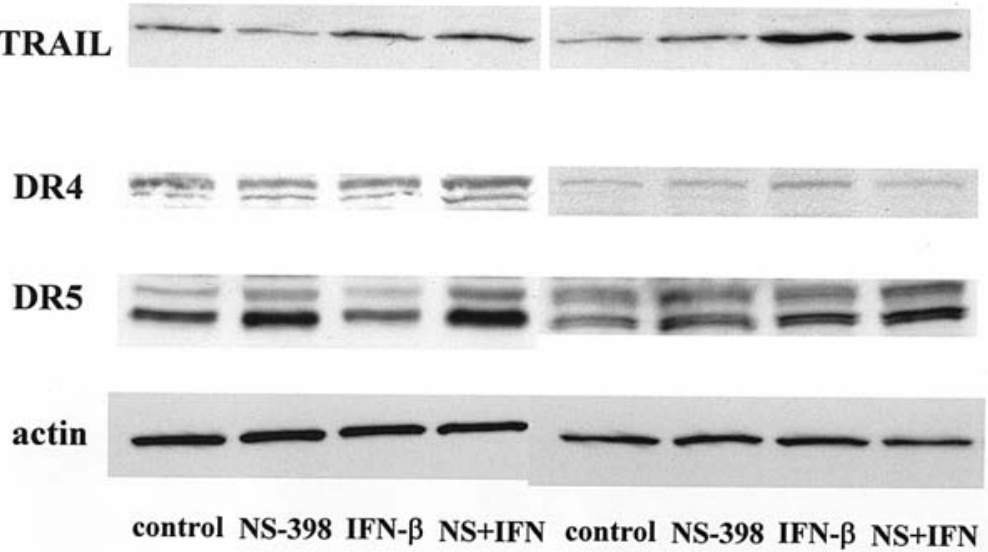

incubated with the following antibodies: goat polyclonal antiactin (Santa Cruz Biotechnology, Santa Cruz, CA, USA); goat polyclonal TRAIL (Santa Cruz Biotechnology), rabbit polyclonal anti-DR4 (Pro Science, Long Beach, CA, USA), goat polyclonal anti-DR5 (Alexis), and rabbit polyclonal anti-COX-2 (Cayman Chemical). After 3 washes for $10 \mathrm{~min}$ each, membranes were incubated with appropriate horseradish peroxidase-conjugated secondary antibodies for $60 \mathrm{~min}$ at RT. Bands were reacted with the ECL detection reagent and captured on X-ray film.

Measurement of caspase activity. After treatment with NS-398 and/or IFN- $\beta$ for the indicated time periods, activity of caspase- 3 and -8 activity in these cells was assayed with an APOPCYTO colorimetric assay kit (MBL, Tokyo, Japan) according to the manufacturer's instruction.

Detection of apoptosis. Apoptotic cells were detected with 4',6-diamidino-2-phenylindole dihydrochloride (DAPI) staining. Briefly, after treatment with NS-398 and/or IFN- $\beta$ for $48 \mathrm{~h}$, the cells were washed 3 times with PBS and stained with $5 \mu \mathrm{g} / \mathrm{ml}$ DAPI (Sigma Chemical Co.) for $30 \mathrm{~min}$ at $37^{\circ} \mathrm{C}$ and observed by fluorescence microscopy.

Real-time RT-PCR. Total cellular RNA was extracted by using TRIzol reagent (Invitrogen, Carlsbad, CA, USA), according to the manufacturer's instruction. Real-time RT-PCR for DR4, DR5, TRAIL, and COX-2 was performed using the ABI PRISM 7700 instrument (Perkin-Elmer Applied Biosystems, Foster City, CA, USA) with gene-specific primers and the SYBR Green I protocol. A total of $1.0 \mu \mathrm{g}$ RNA was reverse-transcribed to complementary DNA (cDNA) in a total volume of $20 \mu 1$, and $1 \mu 1$ of this mixture was used as a template for RT-PCR. The primers sequences were as follows: TRAIL: sense 5'-ACCAACGAGCTGAAGCAGAT-3', antisense 5'-TCCTTGATGATTCCCAGGAG-3'; DR4: sense 5'-CAGAACATCCTGGAGCCTGTAAC-3', anti-sense 5'ATGTCCATTGCCTGATTCTTTGTG-3'; DR5 sense 5'-TGC AGCCGTAGTCTTGATTG-3', anti-sense 5'-GCACCAAG TCTGCAAAGTCA-3'; COX-2: sense 5'-TGAAACCCAC TCCAAACACA-3', anti-sense 5'-AACTGATGCGTGAAGT GCTG-3'; GAPDH: sense 5'-CAACTACATGGTTTACATG TTC-3', anti-sense 5'-GCCAGTGGACTCCACGAC-3'. Relative expression ratios normalized to that of GAPDH were calculated.

In vivo effect of NS-398 and IFN- $\beta$ on HCC proliferation in nude mice. This experiment was approved and performed on the guideline of the Animal Experimentation Committee of the School of Medicine, Keio University. Female athymic nude mice (BALB/C, 5-6 week old, Clea Japan, Tokyo, Japan) were housed under controled temperature and humidity 
in a 12-h light-dark cycle. To create the xenograft model, cultured Huh7 cells ( $1 \times 10^{7}$ cells/mouse) were subcutaneously injected to the back of mice. Tumor size and body weight was measured three times weekly, and tumor volumes $\left(\mathrm{mm}^{3}\right)$ were evaluated as length $\mathrm{x}$ (width) ${ }^{2} \times 1 / 2$. When the tumor volume reached $\sim 150 \mathrm{~mm}^{3}$, the mice were randomly devided into four groups $(\mathrm{n}=10$ each) and treatment was started. NS-398 was suspended in water with gum arabic and given orally with intubation at a dose of $15 \mathrm{mg} / \mathrm{kg}$ every day, and IFN- $\beta$ was intraperitonealy injected at a dose of $5 \times 10^{4} \mathrm{IU} /$ mice three times a week until day 14, and vehicle only was given as control. Four days after the cessation of treatment, on day18, the mice were sacrificed and tumors were resected and fixed with $10 \%$ neutral-buffered formalin, and they were cut into $5-\mu \mathrm{m}$ sections after embedding in paraffin. Apoptotic cell was evaluated by TUNEL method as described before (27) with some modifications. The number of TUNEL positive cells was counted in five randomly chosen non-overlapping areas of each section (magnification $\mathrm{x} 400$ ) and the percentage of positive cells compared with the total tumor cell number was calculated.

Statistical analysis. The data are expressed as mean \pm standard deviation (SD). Differences between the means of two groups were evaluated by the Kruskal-Wallis test or Mann-Whitney U test. A $\mathrm{p}<0.05$ was considered significant.

\section{Results}

COX-2 inhibitor amplified cell death of human hepatoma cells in addition to the effect of IFN- $\beta$. IFN- $\beta$ alone decreased the viability of PLC/PRF/5 cells dose-dependently, but did not decrease the viability of Huh7 cells. Viability of HepG2 cells was inhibited by IFN- $\beta$ alone only at a concentration of $2000 \mathrm{IU} / \mathrm{ml}$. NS-398 alone caused a dose-dependent decrease in the viability of both Huh7 and PLC/PRF/5 cells, but decreased viability of HepG2 only at a concentration of $200 \mu \mathrm{M}$. On the other hand, the combination treatment synergistically decreased cell viability in a dose-dependent manner in all 3 cell lines (Fig. 1A).

Sequential changes in the viability of HepG2 cells are shown in Fig. 1B. At 24 h, there was no synergism between the effects of IFN-B and NS-398, but at later time-points, their effects were synergistically enhanced in a time-dependent manner. IFN- $\beta$ alone resulted in $25 \%$ inhibition, NS-398 alone resulted in $15 \%$ inhibition, while the combination treatment caused $74.8 \%$ inhibition at $96 \mathrm{~h}$.

We further examined the effect of IFN- $\alpha$ on the viability of these cell lines (Fig. 1C). In contrast to the result of IFN- $\beta$ treatment, IFN- $\alpha$ did not significantly decrease cell viability in any of the 3 cell lines, whether it was used alone or in combination with NS-398.

Fig. 1D shows representative phase contrast and fluorescence photomicrographs with DAPI staining in PLC/PRF/5 cells. Combined treatment with IFN-B and NS-398 increased the number of cells with high fluorescence and nuclear condensation to a significantly greater extent than treatment with each agent alone. The morphometric analysis of the number of apoptotic cells in 5 randomly selected frames yielded results similar (data not shown) to those shown in Fig. 1A.

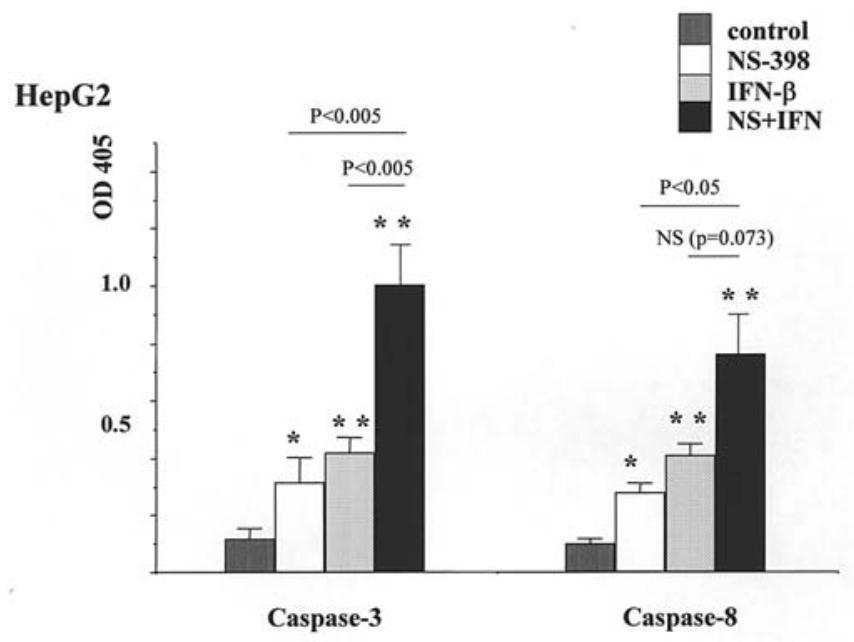

Figure 3. Effect of IFN- $B$ and/or NS-398 on caspase-3 and -8 activity in HepG2 cells. HepG2 cells were treated with IFN-B (1000 IU/ml) and/or NS-398 $(100 \mu \mathrm{M})$ for $24 \mathrm{~h}$, followed by a measurement of the activity of caspase- 3 and -8 using a colorimetric assay kit. Data represent mean \pm SD of 6 samples. ${ }^{*} \mathrm{p}<0.05 ;{ }^{* *} \mathrm{p}<0.005$ compared with control cells.

IFN- $\beta$ up-regulates TRAIL expression and NS-398 up-regulates TRAIL receptor expression. Real-time RT-PCR showed that IFN-ß (1000 IU/ml) remarkably increased the levels of TRAIL mRNA even at $6 \mathrm{~h}$ following the treatment in the 3 cell lines (Fig. 2A), and the expression level was about 400-fold higher than that of control in Huh7 cells. This up-regulation was dose-dependent and up-regulated levels of TRAIL were much lower with IFN- $\alpha$ treatment than with IFN- $\beta$ (Fig. $2 B$ ). IFN- $\beta$ did not alter the level of DR5 mRNA in any of the cell lines, while DR4 mRNA levels were slightly up-regulated in Huh7 and PLC/PRF/5 cells, but not in HepG2 cells. In contrast, treatment with NS-398 $(100 \mu \mathrm{M})$ up-regulated the transcription of TRAIL receptors, and notably, increased DR5 mRNA levels up to 5-fold. TRAIL mRNA levels, however, were not changed by NS-398. Consequently, combination treatment induced the expression of both TRAIL ligand and TRAIL receptor.

A typical result of Western blotting is shown in Fig. 2C. NS-398 and IFN- $\beta$ increased the expression of DR5 and TRAIL, respectively, and combination treatment amplified both expressions.

Caspase activation. Activation of caspase- 8 was induced by either NS-398 or IFN-B alone, and even more so when they were given in combination. The caspase- 8 activity of HepG2 at $24 \mathrm{~h}$ after treatment was about 6-fold higher than that of control cells, followed by the activation of caspase-3 (Fig. 3).

Response to exogenous TRAIL stimulation and blockade by the antibody and PGE2. As shown in Fig. 4, soluble TRAIL at a concentration of $100 \mathrm{ng} / \mathrm{ml}$ reduced the viability of HepG2 cells (83.5\% vs. control). NS-398 enhanced this reduction to $68.3 \%$, while IFN- $\beta$ did not. The enhanced reduction of cell viability with NS-398 was also observed in Huh7 cells.

We then examined effect of the TRAIL neutralizing antibody $(1 \mu \mathrm{g} / \mathrm{ml})$ in HepG2 and Huh7 cells (Fig. 5). In HepG2 cells, $1 \mu \mathrm{g} / \mathrm{ml}$ of the TRAIL neutralizing antibody partially rescued growth suppression induced by NS-398 $(100 \mu \mathrm{M})$ and IFN-B (1000 IU/ml) from 56.2 to $73.7 \%$. In 


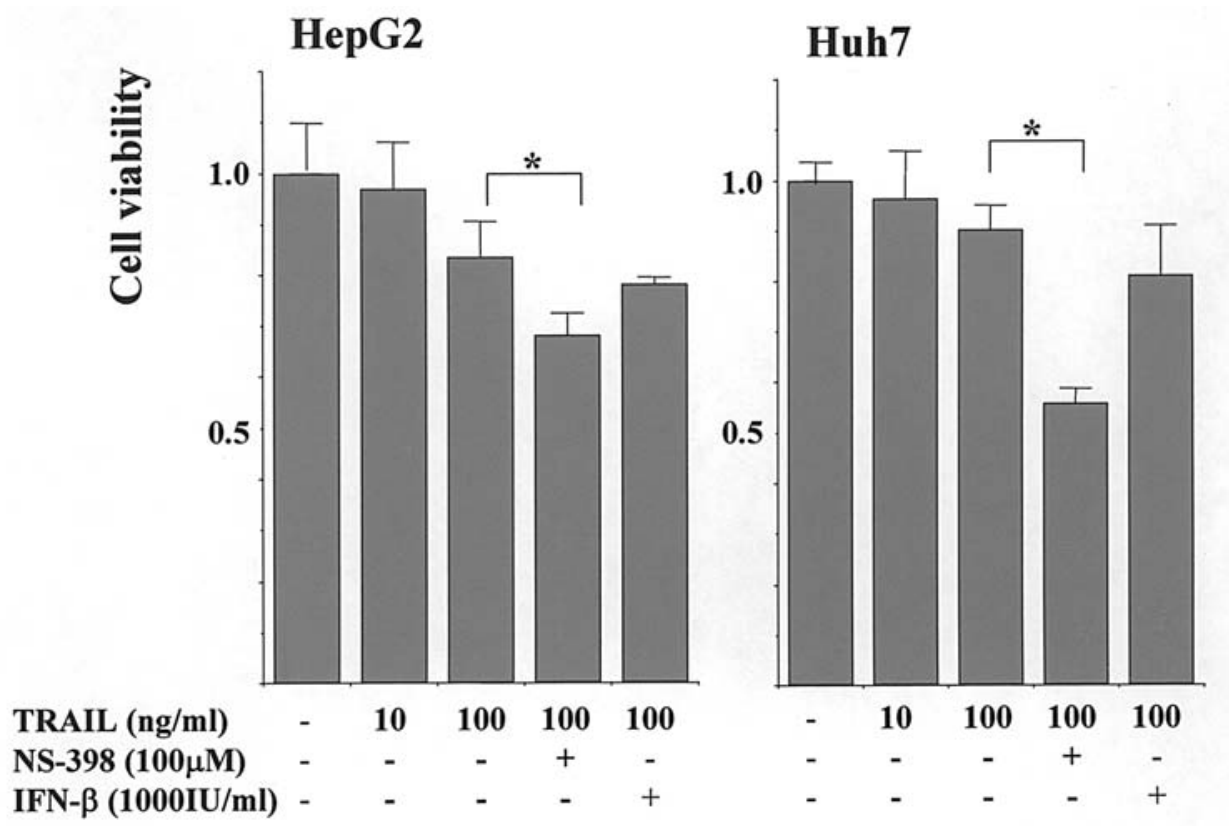

Figure 4. Effect of IFN-B and NS-398 on TRAIL-induced cytotoxicity in HepG2 and Huh7 cells. Cells were treated with recombinant TRAIL (10, 100 ng/ml) in combination with IFN- $\beta(1000 \mathrm{IU} / \mathrm{ml})$ or NS-398 $(100 \mu \mathrm{M})$ for $48 \mathrm{~h}$. Cell viability was determined by MTS assay. Data represent mean \pm SD of 6 samples. ${ }^{*} \mathrm{p}<0.05$ compared with soluble TRAIL $(100 \mathrm{ng} / \mathrm{ml})$-treated cells.
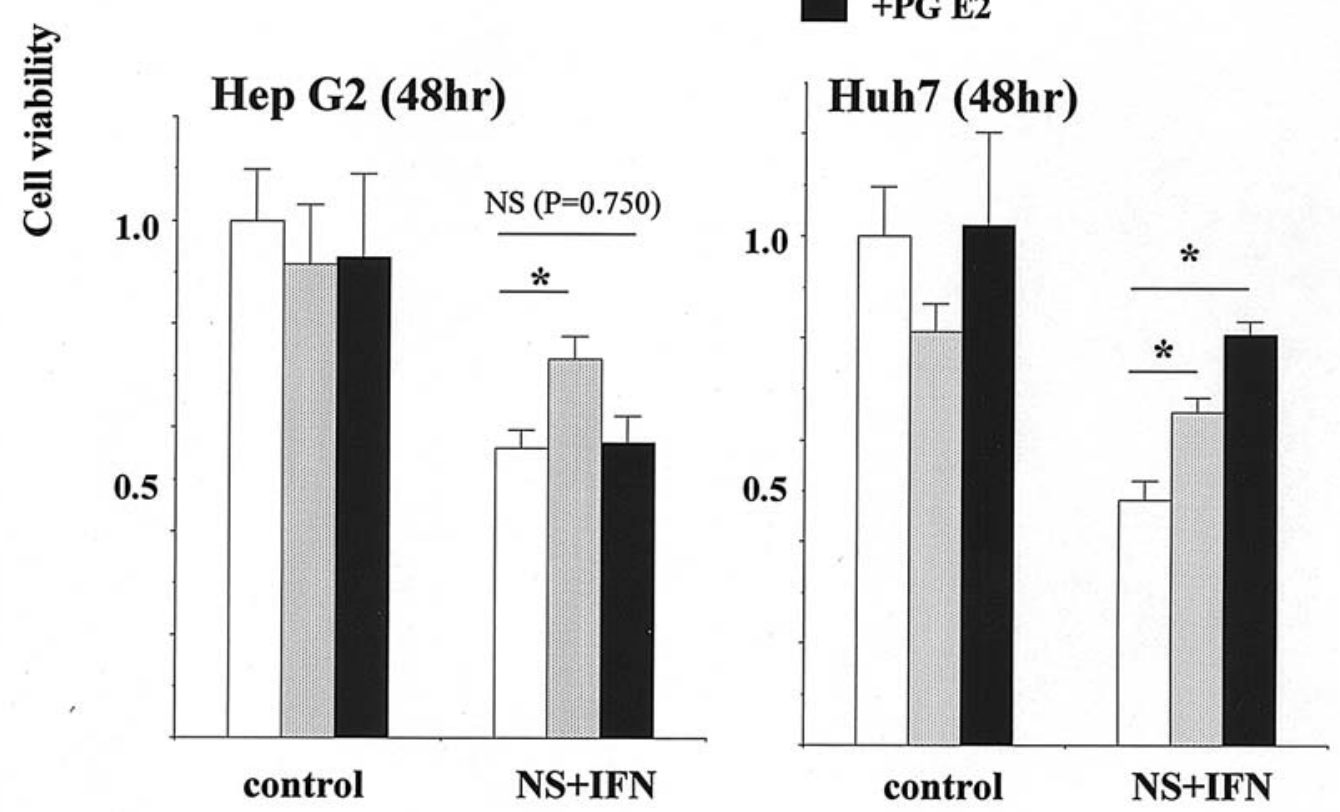

Figure 5. Effect of the anti-TRAIL neutralizing antibody and PGE2 on toxicity induced by IFN-ß and/or NS-398 in HepG2 and Huh7 cells. Cells were treated with IFN-B (1000 IU/ml) and/or NS-398 $(100 \mu \mathrm{M})$ for $48 \mathrm{~h}$ in the absence or presence of the anti-TRAIL neutralizing antibody $(1 \mu \mathrm{g} / \mathrm{ml})$ and PGE2 $(10 \mu \mathrm{M})$. Cell viability was determined by MTS assay. Data represent mean \pm SD of 6 samples. " $p<0.001$ compared with cells incubated in a culture medium.

Huh7 cells, the growth suppression was rescued from 48.3 to $65.5 \%$ in the presence of TRAIL neutralizing antibody. On the other hand, treatment with PGE2 changed the viability of Huh7 cells from 48.3 to $80.5 \%$, while that of HepG2 was not significantly improved (from 56.2 to $57.1 \%$ ).
IFN- $\beta$ increases COX-2 expression. We examined the direct effect of IFN- $\beta$ on COX-2 expression in Huh7 cells. Real-time RT-PCR showed that IFN- $\beta$ remarkably increased COX-2 mRNA levels in a dose-dependent manner (Fig. 6A). Western blotting showed that IFN- $\beta$ increased COX-2 protein levels 
A

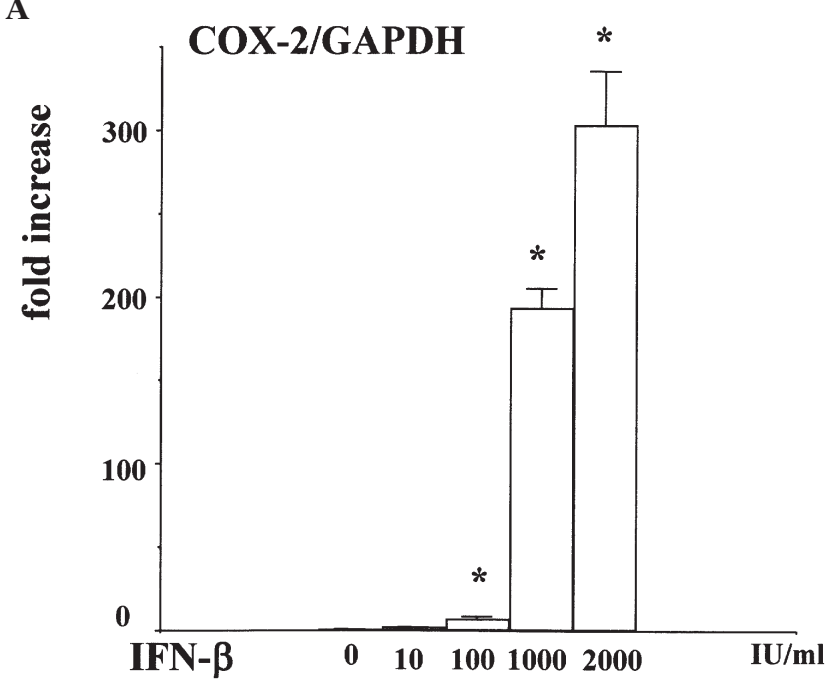

B

\section{COX-2}

actin

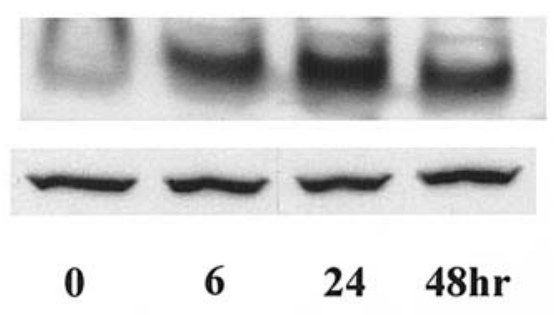

Figure 6. Effect of IFN- $\beta$ on COX-2 expressions in Huh7 cells. A, Cells were treated with IFN- $\beta(0-2000 \mathrm{IU} / \mathrm{ml})$ for $24 \mathrm{~h}$. Expression of COX-2 mRNA was examined by real-time RT-PCR. Data represent mean \pm SD of 4 samples. ${ }^{*} \mathrm{p}<0.05$ compared with control cells. B, Cells were treated with IFN-B (1000 IU/ml) for 6,24 , and $48 \mathrm{~h}$. COX-2 protein levels were examined by Western blotting. Results shown are a representative example from 3 experiments.

in a time-dependent manner, and the peak was detected at $24 \mathrm{~h}$ after stimulation (Fig. 6B).

In vivo effect of $N S-398$ and IFN- $\beta$ on HCC proliferation in nude mice. Even single treatment with either NS-398 or IFN- 3 showed a significant inhibitory effect on HCC development compared with the control group (Fig. 7). Furthermore, tumor volumes in combined treated group became significantly smaller than other three groups on the 5th day and later. Growth inhibitory rate at the end of the experiment (day 18) in the NS-398 treated group, the IFN-B treated group, and the combination treatment group were 50,46 , and $86 \%$, respectively. As shown in Fig. 8, the number of TUNELpositive cells was significantly increased in the combination treatment group.

\section{Discussion}

In this study, we demonstrated that NS-398 and IFN-ß synergistically suppress cell growth and induce apoptosis in human hepatoma cell lines. We found that NS-398 up-regulated the expression of DR, especially that of DR5, while IFN- 3 upregulated the expression of TRAIL, and the combination of both agents induced apoptosis through caspase- 8 and -3 activation. Furthermore, apoptosis induced by NS-398 and IFN- $\beta$ was inhibited by the TRAIL neutralizing antibody in

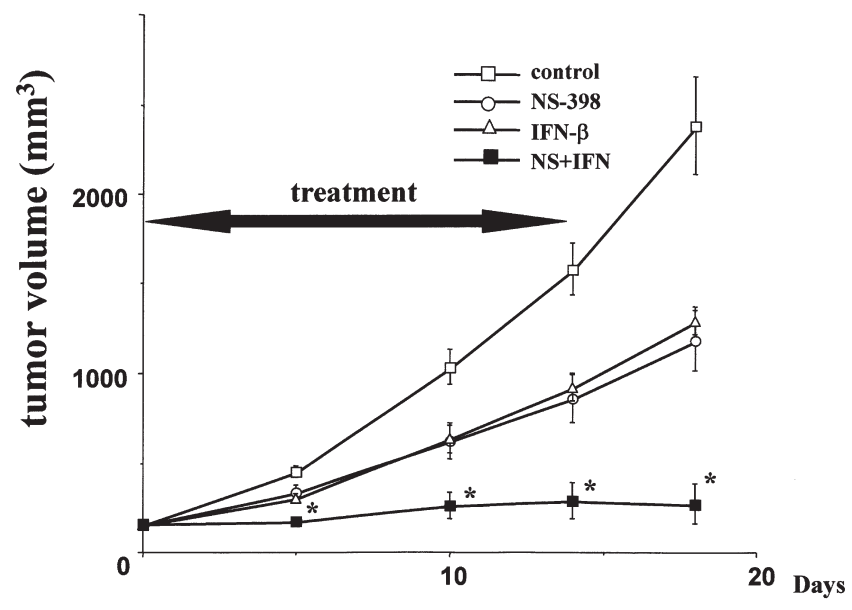

Figure 7. Effect of IFN- 3 and NS-398 on HCC development in nude mice. Administration of IFN-B and NS-398 was started when the tumor volume reached to $\sim 150 \mathrm{~mm}^{3}$. Treatment group consisted of either control group, NS-398 treated group ( $15 \mathrm{mg} / \mathrm{kg}$ p.o., every day), IFN-ß treated group (5x104 IU i.p., 3/week), and both NS-398 and IFN-B treated group. Tumor size was measured at the indicated time-point. Data represent mean $\pm \mathrm{SD}$ of 10 samples. ${ }^{*} \mathrm{p}<0.05$ compared with other group.

both Hep G2 and Huh7 cells. The results demonstrated that these effects are mediated, at least partially, through the TRAIL pathway. At present, the mechanism by which NS398 increases DR5 expression is unknown. However, this effect is most likely p53-independent, since DR5 induction was observed in both p53 wild (HepG2) and p53 mutant (PLC/PRF5 and Huh7) hepatoma cells.

In addition, we examined whether or not the synergism was COX-2 dependent, which has been an area of controversy (28). Several factors are thought to be involved in the mechanism by which COX-2 contributes to tumorigenesis, such as an increase in angiogenesis through the production of vascular endothelial growth factor (VEGF), an increase in invasiveness through the activation of matrix metalloproteinases (MMPs), and an increase in cell adhesion through up-regulation of b1 and $\alpha$ VB3 integrin expression (29). Our results showed that exogenous PGE2 addition partially inhibited apoptosis induced by NS-398+IFN-B in Huh7 cells, but not in HepG2 cells, indicating that the COX-2 dependent pathway is also partially involved in this mechanism. Although we could not fully explain the difference in results between Huh7 and HepG2 cells, it is possible that COX-2 expression under basal conditions in each cell line is a contributing factor. Indeed, the expression level of COX-2 mRNA in Huh7 under basal condition was much higher than that in HepG2 (data not shown). We further investigated whether IFN directly affects the activity of COX-2 in hepatoma cell lines. Recent studies have demonstrated direct activation of the COX-2 gene by IFN- $\gamma$ in mice macrophages through binding to the ISRE elements in the mouse COX-2 promotor which was highly preserved in the human COX-2 gene (30). Furthermore, COX-2 induction by type 1 IFN (IFN- $\alpha$ was also reported in human small non-small cell lung cancer cells (31). As shown in Fig. 6, IFN- 3 up-regulated the amount of COX-2 protein and mRNA levels as early as $6 \mathrm{~h}$, and its peak was detected $24 \mathrm{~h}$ following drug administration. These results suggested 
A
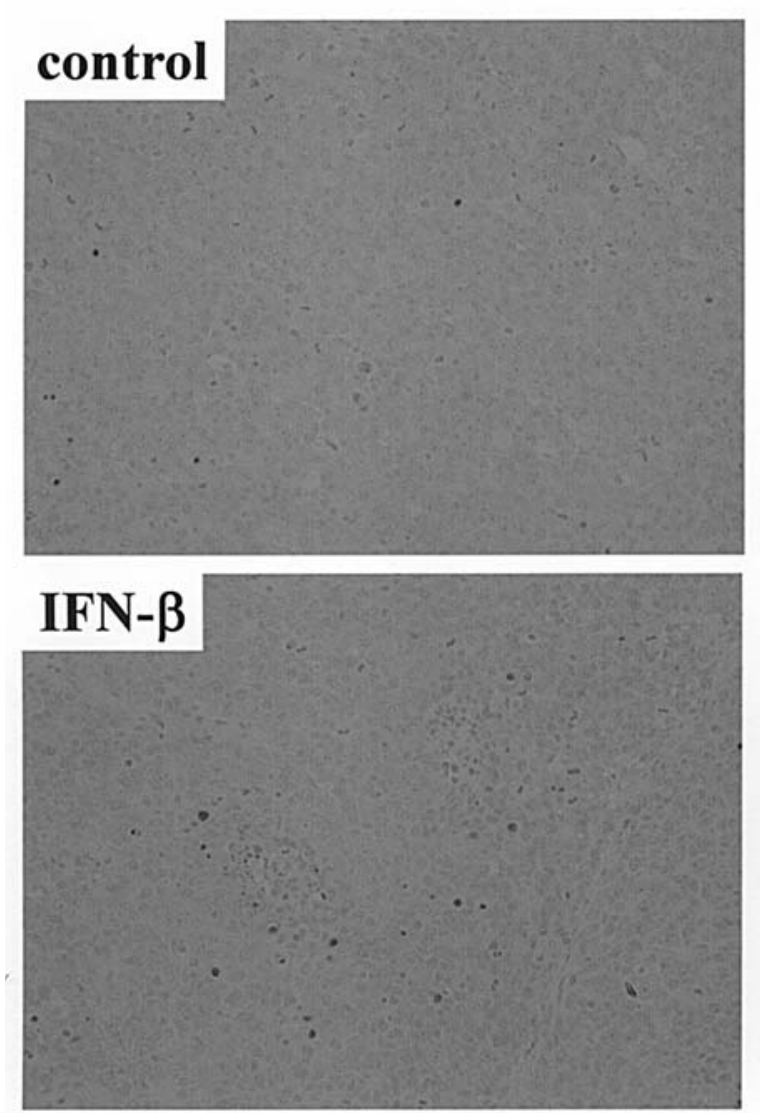

B
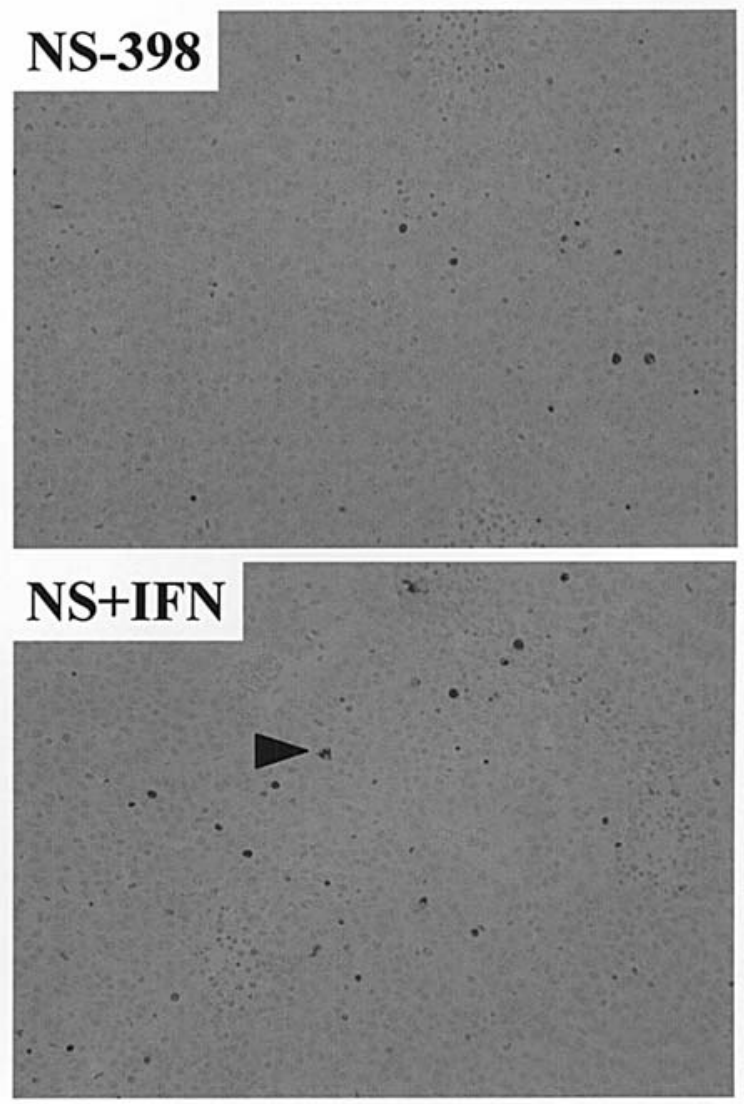

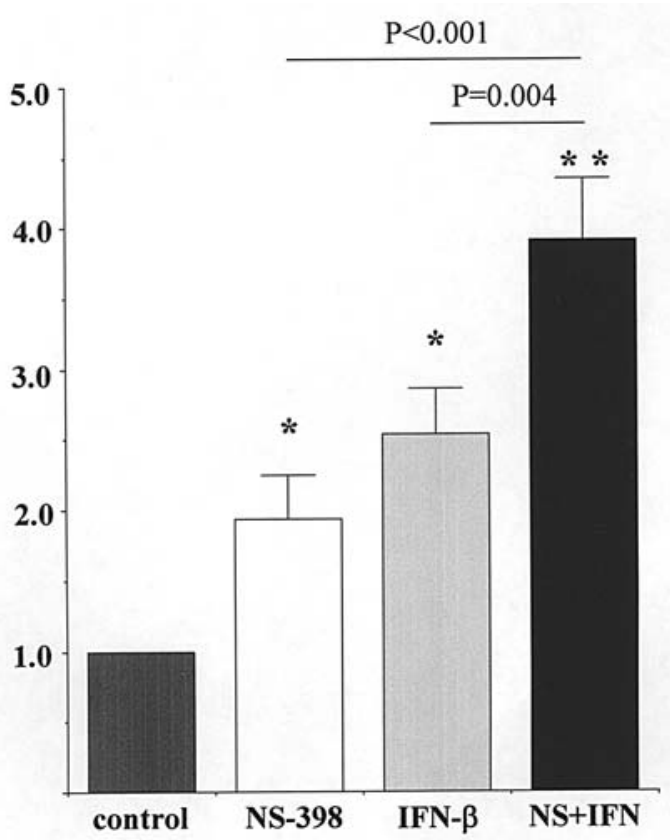

Figure 8. TUNEL staining in tumors derived from mice in each group. A, Representative photographs. Black arrow indicates the apoptotic cell in the tumor (x200). B, Semiquantitative analysis of TUNEL-immunopositive cells. For comparison of the different treatment groups, the control was arbitrarily set to one. Data represent mean \pm SD of 5 samples. ${ }^{*} \mathrm{p}<0.005$ and ${ }^{* *} \mathrm{p}<0.001$ compared with control group.

the involvement of another mechanism in the synergism by NS-398 and IFN-B, at least in certain hepatoma cell lines, i.e., COX-2 inhibitors directly suppress the up-regulated COX-2 activity and subsequent PGE2 production downstream of IFN signaling. IFN-mediated COX-2 induction might also explain why human hepatoma cell lines such as Huh7 were resistant to IFN regardless of TRAIL up-regulation, and why COX-2 inhibitors could overcome the resistance.

Although TRAIL is an attractive candidate for future cancer therapies, several human carcinomas, including HCC, are resistant to TRAIL when used as a monotherapy. Recent studies have shown that some chemotherapeutic agents (32) and radiation (33) sensitize many cancer cells to exogenous TRAILinduced apoptosis, and that this sensitization can be achieved through several mechanisms, such as the upregulation of TRAIL receptors (34), down-regulation of c-FLIP (35), and inhibition of AKT phosphorylation (36). Our results showed that exogenous TRAIL, when treated alone, could not effectively suppress cell growth of HepG2 and Huh7 cells, while NS-398, but not IFN-B, could overcome the TRAIL resistance through DR5 upregulation. Thus, a combination of exogenous TRAIL and COX-2 inhibitors may also be a useful regimen for HCC.

IFN- $\alpha$ and IFN- $\beta$ may have different anti-proliferative effects in many cancers and IFN- $\beta$ has been reported to have greater apoptosis-inducing effects than IFN- $\alpha$ (35-37). In human hepatoma cell lines, IFN- $\beta$ was shown to be more potent anti-proliferative than IFN- $\alpha$, either when used alone or in combination with certain anticancer drugs (38). Our results showed that IFN- $\beta$ had similar anti-proliferative effect as IFN- $\alpha$ when used alone, but IFN- $\alpha$ did not have a synergistic effect with NS-398 at the concentrations tested. We speculated that the extent of TRAIL production might contribute to the difference. The results of real-time RT-PCR (Fig. 2B) revealed that both IFN- $\alpha$ and IFN- $\beta$ up-regulated TRAIL mRNA in a dose-dependent manner, and it is suggested 
that IFN- $\beta$ is a much stronger TRAIL inducer than IFN- $\alpha$ in HepG2 cells.

Several studies have suggested that combined administration of IFN- $\alpha$ with NSAIDs can improve virological response in chronic hepatitis $\mathrm{C}(39,40)$, although the opposite result has also been reported (41). Some of the proposed mechanisms for this synergism include increased STAT1 phosphorylation (42), and upregulation of serum 2'5'-oligoadenylate synthetase (43). Giambartolomei et al showed that maximal STAT1 phosphorylation was achieved when IFN- $\alpha$ was administered at a concentration of $300 \mathrm{IU} / \mathrm{ml}$ (42). In our study, the synergism between IFN-B + NS-398 was achieved in a dose-dependent manner, indicating that the synergistic effect on virological response and that on apoptosis are different mechanisms.

Our in vivo study showed that single treatment of either NS-398 or IFN-B reduced the growth of xenotransplanted HCCs and that combined treatment of NS-398 and IFN-B showed a more inhibitory effect. Immunohistochemical study with TUNEL staining revealed that apoptosis played at least a partial role in the growth inhibition. These results underline and strengthen the effect of combination treatment shown in the in vitro study. One limitation of this nude mouse tumor inplant approach is that it does not allow us to examine the auto-immune response, so further study using another carcinogenic model is needed for future clinical use.

In conclusion, we demonstrated that IFN-B and NS-398 synergistically induce cell death of human hepatoma cells through the TRAIL/death receptor-mediated apoptotic pathway, and possibly through COX-2 inhibition. TRAIL-based cancer therapy is currently used clinically, and our results imply that TRAIL in combination with COX-2 inhibitors could also be an effective therapeutic regimen for the future treatment of HCC. This is the first report to show that the COX-2 inhibitor such as NS-398 can overcome IFN resistance in the treatment of human hepatoma both in vitro and in vivo, and this combination treatment may be an effective chemotherapeutic regimen for the treatment of HCC.

\section{Acknowledgments}

This work was supported by a Grant-in-Aid for Scientific Research from the Japanese Ministry of Education, Scientific and Culture of Japan. We thank Ms. Kyoko Watanabe for secretarial assistance. We acknowledge Dr Gregory Gores, Mayo Clinic, MN, USA, for helpful discussion.

\section{References}

1. Shiratori $\mathrm{Y}$, Shiina $\mathrm{S}$, Teratani T, et al: Interferon therapy after tumor ablation improves prognosis in patients with hepatocellular carcinoma associated with hepatitis C virus. Ann Intern Med 138: 299-306, 2003.

2. Eguchi H, Nagano H, Yamamoto H, et al: Augmentation of antitumor activity of 5-fluorouracil by interferon alpha is associated with up-regulation of p27Kip1 in human hepatocellular carcinoma cells. Clin Cancer Res 6: 2881-2890, 2000.

3. Chen Q, Gong B, Mahmoud-Ahmed AS, Zhou A, Hsi ED, Hussein $\mathrm{M}$ and Almasan A: Apo2L/TRAIL and Bcl-2-related proteins regulate type I interferon-induced apoptosis in multiple myeloma. Blood 98: 2183-2192, 2001.

4. Chawla-Sarkar M, Leaman DW, Jacobs BS and Borden EC: IFN-beta pretreatment sensitizes human melanoma cells to TRAIL/Apo2 ligand-induced apoptosis. J Immunol 169: 847-855, 2002.
5. Morrison BH, Tang Z, Jacobs BS, Bauer JA and Lindner DJ: Apo2L/TRAIL induction and nuclear translocation of inositol hexakisphosphate kinase 2 during IFN-beta-induced apoptosis in ovarian carcinoma. Biochem J 385: 595-603, 2005.

6. Papageorgiou A, Lashinger L, Millikan R, Grossman HB, Benedict W, Dinney CP and McConkey DJ: Role of tumor necrosis factor-related apoptosis-inducing ligand in interferoninduced apoptosis in human bladder cancer cells. Cancer Res 64: 8973-8979, 2004.

7. Ashkenazi A and Dixit VM: Death receptors: signaling and modulation. Science 281: 1305-1308, 1998.

8. Scaffidi C, Fulda S, Srinivasan A, et al: Two CD95 (APO-1/ Fas) signaling pathways. EMBO J 17: 1675-1687, 1998.

9. Walczak H, Bouchon A, Stahl H and Krammer PH: Tumor necrosis factor-related apoptosis-inducing ligand retains its apoptosis-inducing capacity on Bcl-2- or Bcl-xL-overexpressing chemotherapy-resistant tumor cells. Cancer Res 60: 3051-3057, 2000.

10. Legrand A, Vadrot N, Lardeux B, Bringuier AF, Guillot R and Feldmann G: Study of the effects of interferon $\alpha$ on several human hepatoma cell lines: analysis of the signalling pathway of the cytokine and of its effects on apoptosis and cell proliferation. Liver Int 24: 149-160, 2004.

11. Zhang Z, Lai GH and Sirica AE: Celecoxib-induced apoptosis in rat cholangiocarcinoma cells mediated by Akt inactivation and Bax translocation. Hepatology 39: 1028-1037, 2004.

12. Huang Y, He Q, Hillman MJ, Rong R and Sheikh MS: Sulindac sulfide-induced apoptosis involves death receptor 5 and the caspase 8-dependent pathway in human colon and prostate cancer cells. Cancer Res 61: 6918-6924, 2001.

13. Li M, Wu X and Xu XC: Induction of apoptosis in colon cancer cells by cyclooxygenase-2 inhibitor NS398 through a cytochrome c-dependent pathway. Clin Cancer Res 7: 1010-1016, 2001.

14. Eberhart CE, Coffey RJ, Radhika A, Giardiello FM, Ferrenbach S and DuBois RN: Up-regulation of cyclooxygenase 2 gene expression in human colorectal adenomas and adenocarcinomas. Gastroenterology 107: 1183-1188, 1994.

15. Tucker ON, Dannenberg AJ, Yang EK, et al: Cyclooxygenase-2 expression is up-regulated in human pancreatic cancer. Cancer Res 59: 987-990, 1999.

16. Shirvani VN, Ouatu-Lascar R, Kaur BS, Omary MB and Triadafilopoulos G: Cyclooxygenase 2 expression in Barrett's esophagus and adenocarcinoma: ex vivo induction by bile salts and acid exposure. Gastroenterology 118: 487-496, 2000.

17. Bae SH, Jung ES, Park YM, Kim BS, Kim BK, Kim DG and Ryu WS: Expression of cyclooxygenase-2 (COX-2) in hepatocellular carcinoma and growth inhibition of hepatoma cell lines by a COX-2 inhibitor, NS-398. Clin Cancer Res 7: 1410-1418, 2001.

18. Koga H, Sakisaka S, Ohishi M, et al: Expression of cyclooxygenase- 2 in human hepatocellular carcinoma: relevance to tumor dedifferentiation. Hepatology 29: 688-696, 1999.

19. Denda A, Kitayama W, Murata A, et al: Increased expression of cyclooxygenase-2 protein during rat hepatocarcinogenesis caused by a choline-deficient, L-amino acid-defined diet and chemopreventive efficacy of a specific inhibitor, nimesulide. Carcinogenesis 23: 245-256, 2002.

20. Kern MA, Schoneweiss MM, Sahi D, et al: Cyclooxygenase-2 inhibitors suppress the growth of human hepatocellular carcinoma implants in nude mice. Carcinogenesis 25: 1193-1199, 2004.

21. Kern MA, Schubert D, Sahi D, et al: Proapoptotic and antiproliferative potential of selective cyclooxygenase- 2 inhibitors in human liver tumor cells. Hepatology 36: 885-894, 2002.

22. Hu KQ, Yu CH, Mineyama Y, McCracken JD, Hillebrand DJ and Hasan M: Inhibited proliferation of cyclooxygenase-2 expressing human hepatoma cells by NS-398, a selective COX-2 inhibitor. Int J Oncol 22: 757-763, 2003.

23. Johnson AJ, Hsu AL, Lin HP, Song X and Chen CS: The cyclooxygenase- 2 inhibitor celecoxib perturbs intracellular calcium by inhibiting endoplasmic reticulum $\mathrm{Ca}^{2+}$-ATPases: a plausible link with its anti-tumour effect and cardiovascular risks. Biochem J 366: 831-837, 2002.

24. Liu XH, Yao S, Kirschenbaum A and Levine AC: NS398, a selective cyclooxygenase-2 inhibitor, induces apoptosis and downregulates bcl-2 expression in LNCaP cells. Cancer Res 58: 4245-4249, 1998. 
25. Han C, Leng J, Demetris AJ and Wu T: Cyclooxygenase-2 promotes human cholangiocarcinoma growth: evidence for cyclooxygenase-2-independent mechanism in celecoxib-mediated induction of $\mathrm{p} 21 \mathrm{waf} 1 / \mathrm{cip} 1$ and $\mathrm{p} 27 \mathrm{kip} 1$ and cell cycle arrest. Cancer Res 64: 1369-1376, 2004.

26. Liu X, Yue P, Zhou Z, Khuri FR and Sun SY: Death receptor regulation and celecoxib-induced apoptosis in human lung cancer cells. J Natl Cancer Inst 96: 1769-1780, 2004.

27. Nakamoto N, Tada S, Kameyama K, et al: A free radical scavenger, edaravone, attenuates steatosis and cell death via reducing inflammatory cytokine production in rat acute liver injury. Free Radic Res 37: 849-859, 2003.

28. Totzke G, Schulze-Osthoff K and Janicke RU: Cyclooxygenase-2 (COX-2) inhibitors sensitize tumor cells specifically to death receptor-induced apoptosis independently of COX-2 inhibition. Oncogene 22: 8021-8030, 2003.

29. Mayoral R, Fernandez-Martinez A, Bosca L and Martin-Sanz P: Prostaglandin E2 promotes migration and adhesion in hepatocellular carcinoma cells. Carcinogenesis 26: 753-761, 2005.

30. Blanco JC, Contursi C, Salkowski CA, De Witt DL, Ozato K, and Vogel SN: Interferon regulatory factor (IRF)-1 and IRF-2 regulate interferon gamma-dependent cyclooxygenase 2 expression. J Exp Med 191: 2131-2144, 2000.

31. Lee J, Im YH, Jung HH, et al: Curcumin inhibits interferon-alpha induced NF-kappaB and COX-2 in human A549 non-small cell lung cancer cells. Biochem Biophys Res Commun 334: 313-318, 2005

32. Yamanaka T, Shiraki K, Sugimoto K, et al: Chemotherapeutic agents augment TRAIL-induced apoptosis in human hepatocellular carcinoma cell lines. Hepatology 32: 482-490, 2000.

33. Di Pietro R, Secchiero P, Rana R, et al: Ionizing radiation sensitizes erythroleukemic cells but not normal erythroblasts to tumor necrosis factor-related apoptosis-inducing ligand (TRAIL)-mediated cytotoxicity by selective up-regulation of TRAIL-R1. Blood 97: 2596-2603, 2001.

34. Nimmanapalli R, Perkins CL, Orlando M, O'Bryan E, Nguyen D and Bhalla KN: Pretreatment with paclitaxel enhances apo-2 ligand/tumor necrosis factor-related apoptosis-inducing ligandinduced apoptosis of prostate cancer cells by inducing death receptors 4 and 5 protein levels. Cancer Res 61: 759-763, 2001.
35. Hernandez A, Thomas R, Smith F, Sandberg J, Kim S, Chung DH and Evers BM: Butyrate sensitizes human colon cancer cells to TRAIL-mediated apoptosis. Surgery 130: 265-272, 2001.

36. Asakuma J, Sumitomo M, Asano T and Hayakawa M: Selective Akt inactivation and tumor necrosis actor-related apoptosisinducing ligand sensitization of renal cancer cells by low concentrations of paclitaxel. Cancer Res 63: 1365-1370, 2003.

37. Obora A, Shiratori Y, Okuno M, et al: Synergistic induction of apoptosis by acyclic retinoid and interferon-beta in human hepatocellular carcinoma cells. Hepatology 36: 1115-1124, 2002.

38. Damdinsuren B, Nagano H, Sakon M, et al: Interferon-beta is more potent than interferon-alpha in inhibition of human hepatocellular carcinoma cell growth when used alone and in combination with anticancer drugs. Ann Surg Oncol 10: 1184-1190, 2003.

39. Fabris P, Tositti G, Negro F, Marranconi F, Infantolino D, Rassu M and De Lalla F: Interferon alfa-2b alone or in combination with ketoprofen as treatment for interferon-naive chronic hepatitis $\mathrm{C}$ patients. Aliment Pharmacol Ther 13: 1329-1334, 1999

40. Munoz AE, Levi D, Podesta A, et al: Interferon-alpha 2b combined with daily ketoprofen administration improves virological response in chronic hepatitis $\mathrm{C}$ : a prospective and randomised trial. Gut 46: 427-431, 2000.

41. Bastie A, Castera L, Roudot-Thoraval F, Dhumeaux D and Pawlotsky JM: Inhibition of the cyclooxygenase/lipoxygenase pathways to improve interferon alfa efficacy in chronic hepatitis C: a wrong track. Hepatology 31: 547-548, 2000.

42. Giambartolomei S, Artini M, Almerighi C, Moavero SM, Levrero $\mathrm{M}$ and Balsano C: Nonsteroidal anti-inflammatory drug metabolism potentiates interferon alfa signaling by increasing STAT1 phosphorylation. Hepatology 30: 510-516, 1999.

43. Andreone P, Cursaro C, Gramenzi A, Buzzi A, Miniero R, Sprovieri $G$ and Gasbarrini $G$ : Indomethacin enhances serum 2'5'-oligoadenylate synthetase in patients with hepatitis B and C virus chronic active hepatitis. J Hepatol 21: 984-988, 1994. 